International Journal of Current Advanced Research

ISSN: O: 2319-6475, ISSN: P: 2319 - 6505, Impact Factor: SJIF: 5.995

Available Online at www.journalijcar.org

Volume 6; Issue 4; April 2017; Page No. 3566-3569

DOI: http://dx.doi.org/10.24327/ijcar.2017.3569.0316

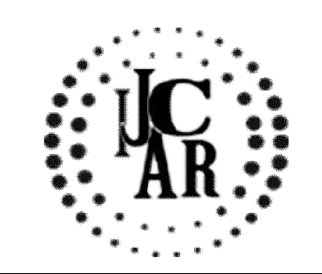

Research Article

\title{
AEROSOL CHARACTERISTICS OVER EAST COAST OF INDIA DURING WINTER TIME
}

\author{
Siriki Srinivasa Rao*
}

Physics Mrs.A.V.N.College, Visakhapatnam Andhra Pradesh, India

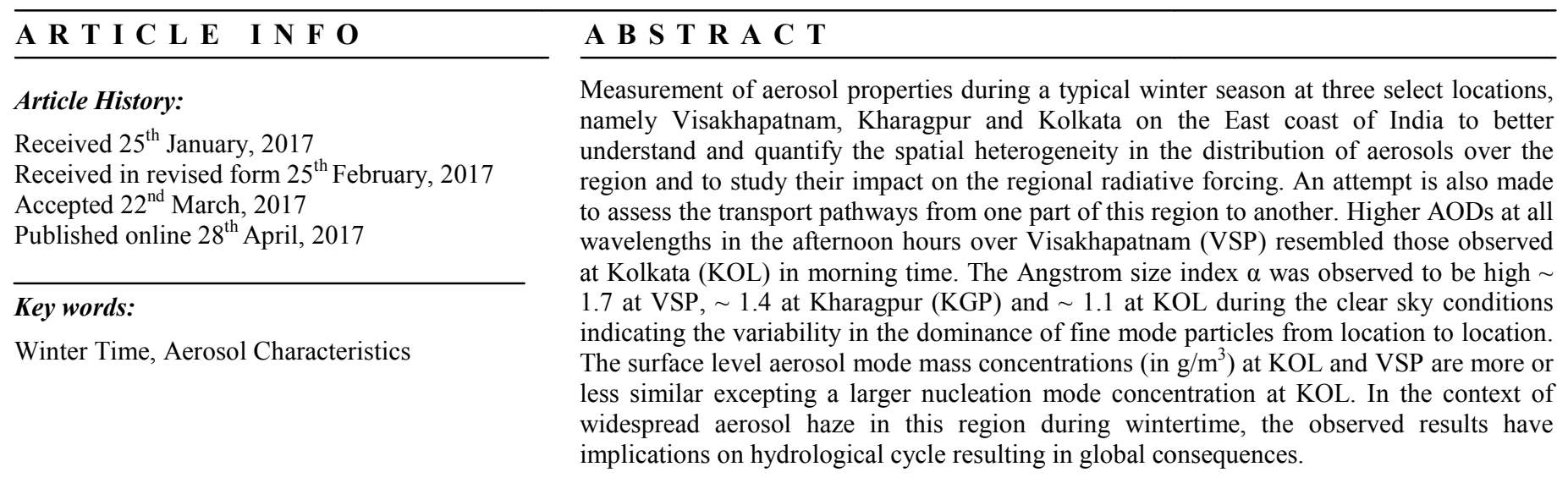

Copyright $₫ 2017$ Siriki Srinivasa Rao. This is an open access article distributed under the Creative Commons Attribution License, which permits unrestricted use, distribution, and reproduction in any medium, provided the original work is properly cited.

\section{INTRODUCTION}

Atmospheric aerosols are the largest sources of uncertainty in the current estimates of radiative forcing in terms of source strength, lifetime and transport. A variety of sources, both natural and anthropogenic, and short lifetimes of aerosols result in spatial and temporal heterogeneous aerosol field, making aerosol characterization and modelling a real challenge [Smirnov et al., 2002]. Indian subcontinent and surrounding regions are rich sources for many kinds of aerosols of natural and anthropogenic origin such as mineral dust, soot, nitrates, sulphates and organic aerosols. This region has been the focus of investigations due to its potential impact on regional and global climate. Rasch et al. [2001] reported that three points of entry are found for the anthropogenic aerosol to the INDOEX region; a strong nearsurface southward flow near Mumbai, a deeper plume flowing south and east off Kolkata coast and a westward flow originating from south East Asia and entering Bay of Bengal. The analysis suggests that India is the dominant source of aerosol in the Arabian Sea and Bay of Bengal near the surface, but Asia, Africa and rest of the world also contribute at higher levels.

In recent years, several regional experimental studies focussed to India and adjoining regions of Asia to characterize the aerosols and to assess their radiative impacts at a regional

\section{*Corresponding author: Siriki Srinivasa Rao}

Physics Mrs.A.V.N. College, Visakhapatnam Andhra

Pradesh, India scale [Satheesh et al., 1999; Lelieveld et al., 2001; Huebert et al., 2003; Vinoj et al., 2004; Girolamo et al., 2004; Moorthy et al., 2005; Tripathi et al., 2005; Niranjan et al., 2005; Ganguly et al., 2006]. However, majority of these studies were conducted either over oceans or were largely weighted by a fair-weather season. Recent observations have revealed pockets of high aerosol loading / optical depth in the north Indian regions around the Ganga basin, particularly during the winter season [Girolamo et al., 2005; Tripathi et al., 2005; Jethva et al., 2005] when the prevailing meteorological conditions are favourable for confinement of aerosols.

It has been reported that the Asian continental outflow of air mass into the open ocean starts in November and continues up to April and therefore, the regional distribution of aerosols over the Indian Ocean during this period is substantially modified by the characteristics of the continental aerosol composition. Realizing the need for characterizing the aerosol optical and physical properties over the Indian sub-continent, the current emphasis is on determining the regional variations in wintertime aerosol characteristics at select locations on the East coast of India to better understand and quantify the spatial heterogeneity in the distribution of aerosols over the region, to study their impact on the regional climate and also to study their transport pathways from one part of this region to another.

\section{Instrumentation and Data}

Comprehensive measurements of the aerosol physical properties at Kharagpur (KGP; $\left.22.31^{0} \mathrm{~N}, 87.31^{\circ} \mathrm{E}\right)$, Kolkata $\left(\mathrm{KOL} ; 22.57^{0} \mathrm{~N}, 88.37^{\circ} \mathrm{E}\right.$ ) and Visakhapatnam (VSP; $17.7^{\circ} \mathrm{N}$, 
$83.3^{0} \mathrm{E}$ ) were carried out. Kharagpur is located just at the mouth of the pollution outflow vent from the north Indian region into Bay of Bengal., the average wind pattern over Indian sub-continent indicate that the surface level wind flow is predominantly from the northern polluted continent toward the ocean region (i.e., into Bay of Bengal) and down south, the flow pattern also shows winds from the Bay of Bengal to south Arabian sea across the peninsula. The clear sky days over Kharagpur are characterized by $10 \mathrm{~km}$ visibility, $\sim 45 \%$ relative humidity $(\mathrm{RH})$ and $\sim 30^{\circ} \mathrm{C}$ ambient temperatures.

The measurements include the (1) aerosol spectral optical depth at 5 wavelengths centered about $0.38,0.44,0.5,0.675$, $0.87 \mu \mathrm{m}$ using a MICROTOPS II Sun photometer (Solar Light Co., United States), with a Global Positioning System (GPS) receiver attached with the photometer to provide information on the location, altitude and pressure, (2) nearsurface aerosol mass concentrations using a 10 channel Quartz Crystal Microbalance (QCM) Impactor (California Measurements Inc., United States), whose 50\% aerodynamic diameters are $25,12.5,6.4,3.2,1.6,0.8,0.4,0.2,0.1$, and $0.05 \mu \mathrm{m}$, respectively, with an air inlet at a flow rate of $0.24 \mathrm{~L}$ $\mathrm{min}^{-1}$ and sampled for a duration of $120 \mathrm{~s}$ (at KGP and KOL) and $300 \mathrm{~s}$ (at VSP),

\section{RESULTS AND DISCUSSION}

\section{Spectral aerosol optical depths and Angstrom exponents}

The aerosol optical depth (AOD or $\tau_{\lambda}$ ), which is the integral of the atmospheric extinction coefficient from the surface to the top of the atmosphere, is an important parameter for visibility degradation (due to atmospheric pollution), solar radiation extinction, climate effects, and tropospheric corrections in remote sensing [Dubovik et al., 2002].
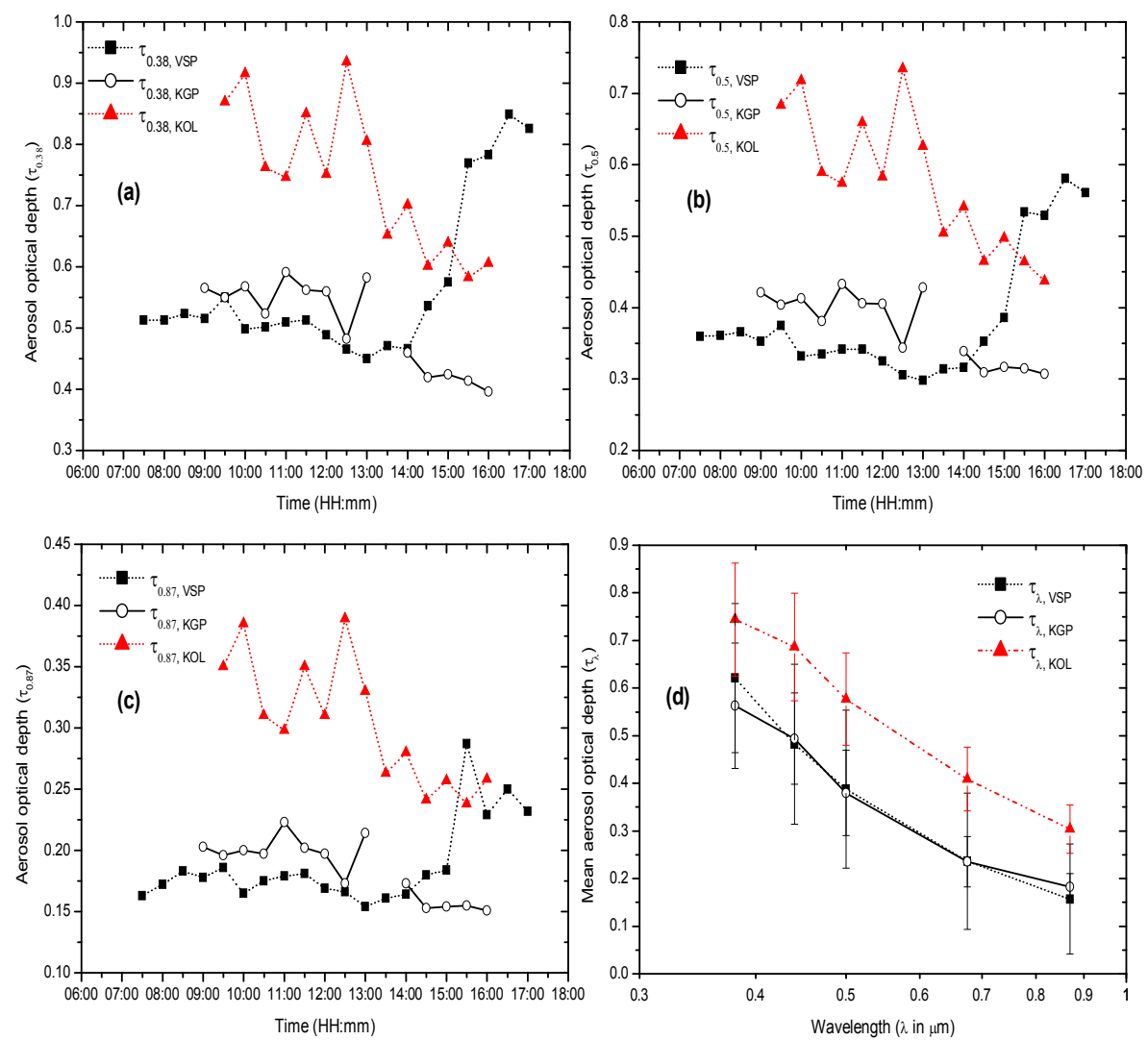

Figure 1 Temporal variation of aerosol optical depths over Visakhapatnam (VSP), Kharagpur (KGP) and Kolkata (KOL) at (a) $0.38 \mu$ m, (b) $0.5 \mu$ m, and (c) $0.87 \mu \mathrm{m}$ on typical clear sky days of observation. (d) Spectral variation of mean aerosol optical depth over VSP, KGP and KOL. 
Mean seasonal diurnal variability over different geographical regions is valuable information to take into account while using instantaneous aerosol optical depth data to assess the aerosol radiative forcing.

Figure 1 (d) show the mean aerosol optical depth spectra for the available clear sky days respectively at Kharagpur and Kolkata during December 2004 (ISRO-GBP Land Campaign II) and at Visakhapatnam during February 2005The Angstrom size index $(\alpha)$ was observed to be high $\sim 1.7$ at VSP, $\sim 1.4$ at $\mathrm{KGP}$ and $\sim 1.1$ at KOL during the clear sky conditions in winter time, indicating the variability in the dominance of fine mode particles from location to location.

The mean spectral variation of AOD over Visakhapatnam and Kharagpur during the period of observation remained almost coincidental with a slight variation in the shorter and longer wavelengths, while over Kolkata the spectral AOD was high indicating increased columnar abundance in all size regimes. Nair et al. [2007] reported that both the long range transport of aerosols from the west and/or the movement of the cool meteorological front from the west to east would be responsible for the day to day changes in the aerosol concentrations over Kharagpur.

\section{Role of transport}

With a view to examine the role of long-range transport of aerosols in causing changes in the optical depth, composition, and physical characteristics of aerosols, the 7-day back trajectories for all the days on which the AOD data were available using the HYbrid Single Particle Legrangian Integrated Trajectory (HYSPLIT) model of the National Oceanic and Atmospheric Administration (NOAA) [Draxler and Rolph, 2003]. The 7-day period was considered in view of the typical residence time of $\geq 1$ week for aerosols in the lower troposphere during the dry period. These trajectories usually back trace the course of an aerosols parcel, which reaches the particular altitude over the observation site, in space (latitude, longitude and altitude) and time (days), backward up to seven days.
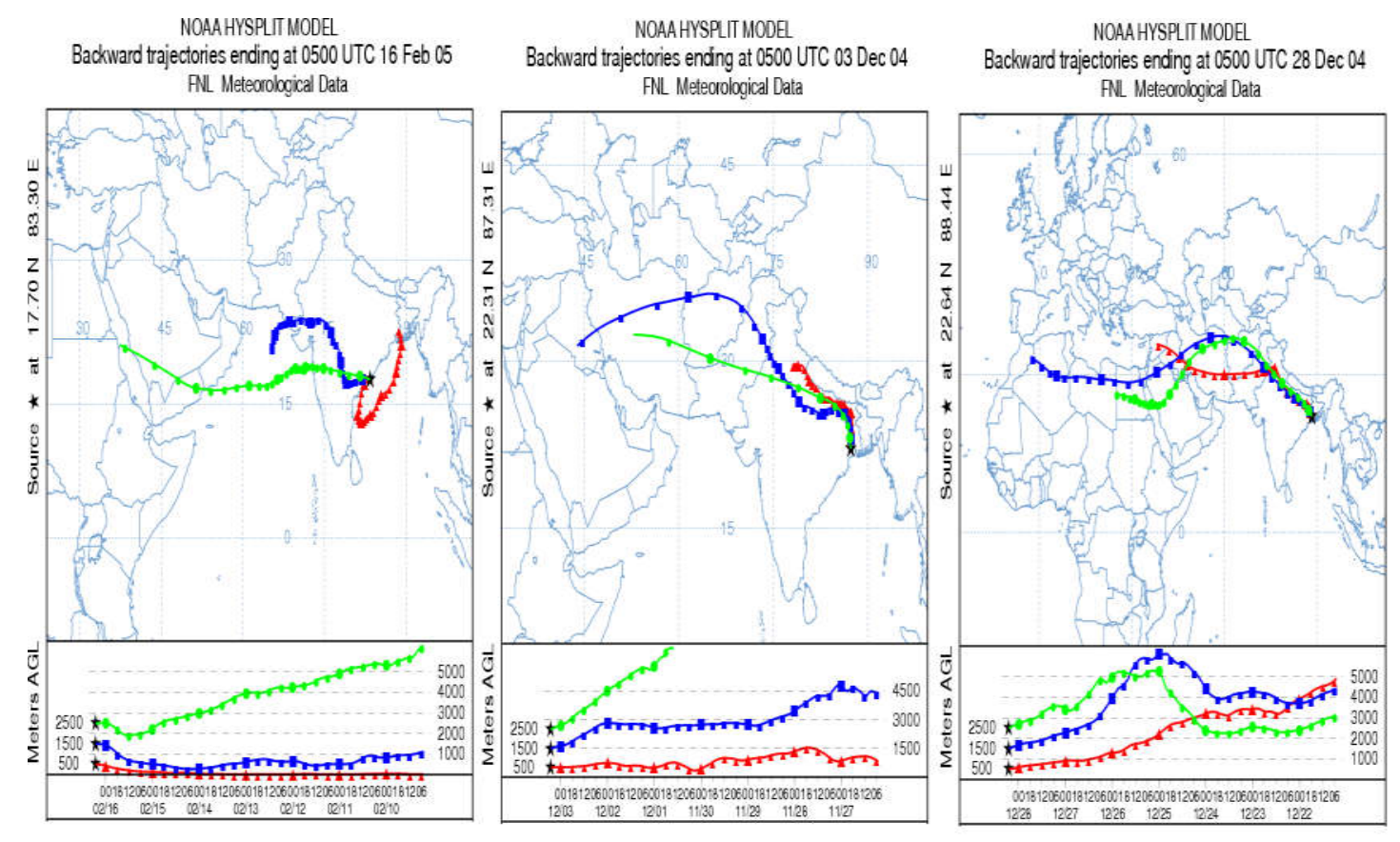

Figure 2 HYSPLIT 7-day back trajectories (at 1030 IST) obtained at $500 \mathrm{~m}, 1500 \mathrm{~m}$ and $2500 \mathrm{~m}$ asl on (a) 16 February 2005 (over VSP), (b) 3 December 2004 (over KGP) and (c) 28 December 2004 (over KOL).
Figure 2 shows the 7-day back trajectories (at 1030 IST) obtained at $500 \mathrm{~m}, 1500 \mathrm{~m}$ and $2500 \mathrm{~m}$ asl on (a) $16 \mathrm{Feb} 2005$ (at VSP), (b) 3 Dec 2004 (at KGP) and (c) 28 Dec 2004 (at $\mathrm{KOL}$ ). To the Visakhapatnam, the air masses were originating from the African region and Arabian Sea traversing through peninsula at constant altitude nearer to the surface level and ascended to $500 \mathrm{~m}$ and $1500 \mathrm{~m}$, while the air parcel at $2500 \mathrm{~m}$ has descended from higher altitudes from the Bangladesh coast. In the case of the air masses reaching Kharagpur and Kolkata on the respective indicated days, the source regions were from northern India, Arabia and African region. Almost all the air masses were descended from high altitudes of source regions indicating the transformation of fine particles to accumulation or coarse mode particles.

It was also observed that there is no significant change in the pathways of the air masses at different altitudes reaching the source locations in the afternoon hours. Thus, it can be inferred that the increase in AODs at $0.38 \mu \mathrm{m}, 0.5 \mu \mathrm{m}$ and $0.87 \mu \mathrm{m}$ over Visakhapatnam in the afternoon showing an increasing trend while contradicting with those of Kharagpur and Kolkata, are not due to any role of long range air mass transport. Higher AODs at all wavelengths in the afternoon hours over Visakhapatnam may be due to the possible role of higher surface wind speeds in the resulting entrainment or convection of drier air mass into the region of land-sea breeze mixing or building up of strong convective activity by afternoon resulting in an increase in moisture content in the lower atmosphere.

\section{Acknowledgements}

I express my deepest sense of gratitude and sincere thanks to my research supervisor Prof.K.Niranjan, Andhra University, Visakhapatnam for his able guidance, constant encouragement and help in my research work. 


\section{References}

Devara, P.C.S., G. Pandithurai, P.E. Raj, S. Sharma (1996), Investigations of aerosol optical depth variations using spectroradiometer at an urban station, Pune, J. Aerosol. Sci., 27, 621-632.

Draxler, R. R., and G.D. Rolph (2003), HYSPLIT (Hybrid Single Particle Lagrangian Integrated Trajectory) model access (Available online at http://www.arl.noaa.gov/ready/hysplit.html).

Dubovik, O., B.N. Holben, T.F. Eck, A. Smirnov, Y.J. Kaufman, M.D. King, D. Tanre, and I. Slutsker (2002), Variability of absorption and optical depth of key aerosol types observed in worldwide locations, $J$. Atmos. Sci., 59, 590-608.

Eck. T.F., B.N. Holben, J.S. Reid, O. Dubovic, A. Smirnov, N.T. O’Neill, I. Slutsker, and S. Kinne (1999), Wavelength dependence of the optical depth of biomass burning, urban, and desert dust aerosols, J. Geophys. Res., 104(D24), 31333-31349.

Ganguly, D., H. Gadhavi, A. Jayaraman, T.A. Rajesh, A. Misra (2005), Single scattering albedo of aerosols over the central India: Implications for the regional aerosol radiative forcing, Geophys. Res. Lett., 32, L18803, doi: 10.1029/2005GL023903.

Ganguly, D., A. Jayaraman, T.A. Rajesh, and H. Gadhavi (2006), Wintertime aerosol properties during foggy and nonfoggy days over urban centre Delhi and their implications on shortwave radiative forcing, J. Geophys. Res., 111, D15217, doi: 10.1029/2005J D007029.

Girolamo, Di. L., T.C. Bond, D. Bramer, D.J. Diner, F. Fettinger, R.A. Kahn, J.V. Martonchik, M.V. Ramana, V. Ramanathan, and P.J. Rasch (2004), Analysis of Multi-angle Imaging Spectro-radiometer (MISR), aerosol optical depths over greater India during winter 2001-2004, Geophys. Res. Lett., 31, L23115, doi: 10.1029/2004GL021273.

Huebert, B., T. Bates, P.B. Russell, G. Shi, Y.J. Kim, K. Kawamura, G. Carmichael, and T. Nakajima (2003), An overview of ACE-Asia: Strategies for quantifying the relationships between Asian aerosols and their climatic impacts, J. Geophys. Res., 108(D23), 8633, doi: 10.1029/2003JD003550.

Jethva, H., S.K. Satheesh, and J. Srinivasan (2005), Seasonal variability of aerosols over the Indo-Gangetic basin, J. Geophys. Res., 110, D21204, doi: 10.1029/2005JD005938.

Kaufman, Y.J., D. Tanre, and O. Boucher (2002), A Satellite view of aerosols in the climate system, Nature, 419, 215-223.

Lelieveld, J., P.J. Crutzen, V. Ramanathan, M.O. Andreae, C.A.M. Brenninkmeijer, T. Campos, G.R. Cass, R.R. Dickerson, H. Fischer, J.A. de Gouw, A. Hansel, A. Jefferson, D. Kley, A.T.J. de Laat, S. Lal, M.G. Lawrence, J.M. Lobert, O.L. Mayol-Bracero, A.P. Mitra, T. Novakov, S.J. Oltmans, K.A. Prather, T. Reiner, H. Rodhe, H.A. Scheeren, D. Sikka, J. Williams (2001), The Indian Ocean Experiment: Widespread air pollution from south and southeast Asia, Science, 291, 1031-1035.
Moorthy, K.K. , S.V. Sunilkumar, P.S. Pillai, et al.(2005), Wintertime spatial characteristics of boundary layer aerosols over peninsular India, J. Geophys. Res., 110(D8), art.no. D08207, doi: 10.1029/2004JD005520, $1-11$.

Nair, V.S., K. Krishna Moorthy, Denny P. Alappattu, P.K. Kunhikrishnan, Susan George, Prabha R. Nair, S. Suresh Babu, B. Abish, S.K. Satheesh, Sachchida Nand Tripathi, K. Niranjan, B.L. Madhavan, V. Srikant, C.B.S. Dutt, K.V.S. Badrinath, and R. Ramakrishna Reddy (2007), Wintertime aerosol characteristics over the Indo-Gangetic Plain (IGP): Impacts of local boundary layer processes and long-range transport, $J$. Geophys. Res., 112, D13205, doi: 10.1029/2006JD008099.

Niranjan, K., B. Melleswara Rao, P.S. Brahmanandam, B.L. Madhavan, V. Sreekanth, and K. Krishna Moorthy (2005), Spatial characteristics of aerosol physical properties over the northeastern parts of peninsular India, Ann. Geophys., 23, 3219-3227.

Niranjan, K., V. Sreekanth, B.L. Madhavan and K. Krishna Moorthy (2007), Aerosol physical properties and Radiative forcing at the outflow region from the IndoGangetic plains during typical clear and hazy periods of wintertime, Geophys. Res. Lett., 34, L19805, doi: 10.1029/2007GL031224.

Rasch, P.J., W.D. Collins, and B.E. Eaton (2001), Understanding the Indian Ocean Experiment (INDOEX) aerosol distributions with an aerosol assimilation, J. Geophys. Res., 106, 7337-7355.

Satheesh, S.K., V. Ramanathan, X. Li-Jones, J.M. Lobert, I.A. Podgorny, J.M. Prospero, B.N. Holben, and N.G. Leob (1999), A model for the natural and anthropogenic aerosols over the tropical Indian Ocean derived from Indian Ocean Experiment data, $J$. Geophys. Res., 104, 27421-27440.

Singh, R.P., S. Dey, S. N. Tripathy, and V. Tare (2004), Variability of aerosol parameters over Kanpur, northern India, J. Geophys. Res., 109, D23206, doi: 10.1029/2004JD004966.

Smirnov, A., Holben, B.N., Kaufman, Y.J., Dubovik, O., Eck, T.F., Slutsker, I., Paitras, C., and Halthore, R.N. (2002), Optical properties of atmospheric aerosol in maritime environments, J. Atmos. Sci., 59, $501-523$.

Vinoj, V., S.S. Babu, S.K. Satheesh, K. Krishna Moorthy, and Y.J. Kaufman (2004), Radiative forcing by aerosols over the Bay of Bengal region derived from shipborne, island-based, and satellite (Moderate Resolution Imaging Sepctroradiometer) observations, J. Geophys. Res., 109, D05203, doi: 10.1029/2003JD004329. 